\title{
Geochemistry of metamorphic rocks from Mizoguchi, western Tottori Prefecture, Japan and its geological significance
}

\author{
Toshio Nozaka, Hirofumi Masunari and Seiji Tamiya \\ Department of Earth Sciences, Faculty of Science, Okayama \\ University, Okayama 700-8530, Japan
}

\begin{abstract}
The Mizoguchi area, Southwest Japan, has been interpreted as a western continuation of the Hida terrane, based on the similarity of the mineralogy and radiometric age of metamorphic rocks. However, new geochemical data show metapelite and metabasite from the Mizoguchi area differ from those of the Hida terrane in the following points. i) Metapelite is relatively rich in Sc compared to $\mathrm{La}$ and $\mathrm{Th}$, and show gently inclined chondrite-normalized REE patterns. ii) In discrimination diagrams for basaltic rocks, metabasite plots in the fields of arc tholeiites or N-MORBs; however, they are relatively depleted in light REEs but much richer in LIL elements than N-MORBs. From these geochemical features the Mizoguchi metamorphic rocks are interpreted to have formed in the fore-arc region of an oceanic island arc. This is in contrast to generally accepted continental setting for the Hida area and suggests the two areas are geologically distinct.
\end{abstract}

\section{Introduction}

Ishiga et al. (1989) report metamorphic rocks from the Mizoguchi area, Tottori Prefecture, Chugoku District, and regard them as exposures of a western continuation of the Hida terrane, central Japan (Fig. 1a). The Hida terrane used to be considered as Precambrian basement underlying the geosynclinal sediments of Southwest Japan, but recently it has been re-interpreted as a nappe that is composed mainly of metamorphosed Paleozoic formations and thrust over younger accretionary complexes (Komatsu et al., 1985; Isozaki and Maruyama, 1991; Sohma and Kunugiza, 1993). The Hida terrane consists dominantly of gneissose rocks, "the Hida gneisses", accompanied locally by schistose rocks, "the Unazuki schists" along its eastern margin (Fig. 1a). Both the gneisses and schists underwent medium $\mathrm{P} / \mathrm{T}$ metamorphism at around 230 to $250 \mathrm{Ma}$, probably associated with the development of orogenic belts in China and/or Korea (Hiroi, 1978; 1981; Suzuki et al., 1989; Sohma and Kunugiza, 1993; Komatsu et al., 1993; Arakawa et al., 2000). To help understand the tectonic evolution of eastern Asia during Paleozoic time, it is

T. Nozaka,nozaka@cc.okayama-u.ac.jp Corresponding author important to clarify the spatial distribution of the Hida terrane. However, this process is hindered by later igneous and tectonic events such as Mesozoic granitic intrusions and the Cenozoic opening of the Sea of Japan.

Whether or not the Hida terrane continues into the Chugoku District is a contentious issue. The long and widely accepted idea that Oki-Dogo, an island in the Sea of Japan (Fig. 1a), is a continuation of the Hida terrane has recently been criticized, mainly based on whole-rock chemical analyses and paleogeographic reconstructions (Sohma et al., 1990; Isozaki and Maruyama, 1991; Sohma and Kunugiza, 1993; Jin and Ishiwatari, 1997; Arakawa et al, 2001). However, geochemical characterization of the Oki metamorphic complex is hampered by migmatization (Kobayashi et al, 1980), which makes it difficult to determine the chemical compositions of the original rocks without very careful consideration to the problem of redistribution of elements. In contrast to the metamorphic rocks of OkiDogo, those of Mizoguchi are of lower grade and not migmatized, and accordingly suitable for comparative geochemical studies. The geochemical data we report here are opposed to the generally held view and give new constraints on the tectonic evolution of eastern 


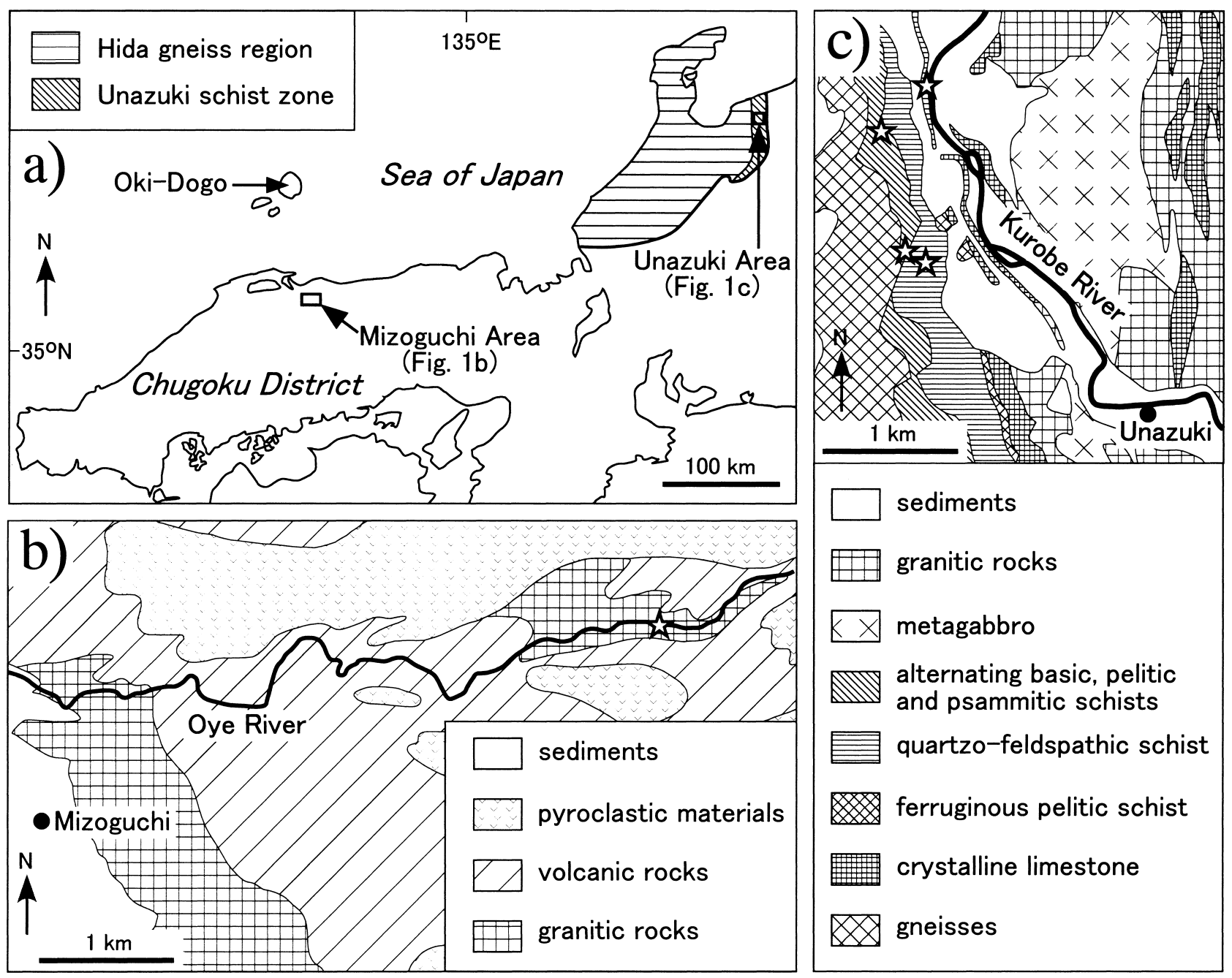

Figure 1. Locality map of the Mizoguchi area and the Hida terrane (a) (after Sohma and Kunugiza, 1993; Arakawa, 2000), and geological sketch maps of the Mizoguchi and Unazuki areas (b, c) (after Ohta, 1962; Hiroi, 1978). The Mizoguchi metamorphic rocks are not exposed on a mappable scale. Stars indicate sampling localities.

Asia.

\section{Sample description}

The exposures of the Mizoguchi metamorphic rocks are scarce due to the Cenozoic cover of volcanic and pyroclastic materials from the Daisen volcano (Fig. 1b; Ohta, 1962). We collected several specimens of pelitic and basic rocks at Loc. 1 of Ishiga et al. (1989) along the Oye River, where the metamorphic rocks are locally exposed and included in granitic bodies of Cretaceous or Jurassic age (Miyamoto et al., 2000).

The Mizoguchi metamorphic rocks commonly have grain sizes ranging from 0.1 to $0.5 \mathrm{~mm}$. Although Ishiga et al. (1989) have referred to them as "gneisses", they do not show typical gneissose structures and are more similar in grain size to the Unazuki schists than the much coarser-grained gneisses of Hida and Oki-Dogo.
Metapelite from the Mizoguchi area commonly shows the mineral association:

biotite + plagioclase $+\mathrm{K}$-feldspar + quartz,

with or without garnet, cummingtonite and hornblende. The biotite and cummingtonite form lepidoblastic and nematoblastic textures, respectively. Actinolite and chlorite also occur partially replacing biotite and cummingtonite.

Metabasite generally shows a granoblastic texture and a weak foliation is only locally developed. Typically the mineral association is:

green hornblende + plagioclase + quartz,

with or without biotite and titanite. The occurrences of secondary minerals such as epidote and calcite forming veinlets and chlorite replacing biotite are also locally common. The fine-grained, massive and homogeneous 
Table 1. Petrographic characteristics of metamorphic rocks from Mizoguchi and Unazuki

\begin{tabular}{|c|c|c|c|c|c|c|c|}
\hline $\begin{array}{l}\text { Locality } \\
\text { Specimen No. } \\
\text { Rock Type }\end{array}$ & $\begin{array}{c}\text { M } \\
840703 \\
\text { pelitic }\end{array}$ & $\begin{array}{c}\text { M } \\
840704 \\
\text { pelitic }\end{array}$ & $\begin{array}{c}\text { M } \\
840701 \\
\text { pelitic }\end{array}$ & $\begin{array}{c}\text { M } \\
852801 \\
\text { pelitic }\end{array}$ & $\begin{array}{c}\mathrm{M} \\
852802 \\
\text { pelitic }\end{array}$ & $\begin{array}{c}\text { M } \\
990905 \\
\text { basic }\end{array}$ & $\begin{array}{c}\text { M } \\
990906 \\
\text { basic }\end{array}$ \\
\hline \multicolumn{8}{|l|}{ Major silicate minerals } \\
\hline Qz & + & + & + & + & + & + & + \\
\hline $\mathrm{Pl}$ & + & + & + & + & + & + & + \\
\hline Kfs & + & + & + & - & - & - & - \\
\hline $\mathrm{Bt}$ & + & + & + & + & + & - & - \\
\hline Mus & - & - & - & - & - & - & - \\
\hline Grt & - & + & - & - & - & - & - \\
\hline Ep & - & + & - & - & - & - & - \\
\hline $\mathrm{Hb}$ & - & - & - & + & - & + & + \\
\hline $\mathrm{Cm}$ & + & - & + & - & - & - & - \\
\hline Texture & $\mathrm{L}$ & $P$ & $\mathrm{~L}, \mathrm{~N}$ & $\mathrm{~L}$ & $\mathrm{~L}$ & G & G \\
\hline \multicolumn{8}{|l|}{ Grain size (mm) } \\
\hline Variation & $0.1-2.0$ & $0.1-1.0$ & $0.2-0.5$ & $0.2-0.8$ & $0.1-1.0$ & $0.05-0.5$ & $0.05-0.5$ \\
\hline Most frequent size & 0.2 & 0.2 & 0.4 & 0.3 & 0.3 & 0.3 & 0.2 \\
\hline Locality & $\mathbf{M}$ & KK & KK & KB & $\mathrm{KB}$ & $\mathrm{KB}$ & $\mathrm{KB}$ \\
\hline Specimen No. & 990914 & 5 & 6 & 11 & 19 & 14 & 24 \\
\hline Rock Type & basic & Bt schist & Bt schist & Bt schist & Bt schist & Hb schist & Hb schist \\
\hline \multicolumn{8}{|l|}{ Major silicate minerals } \\
\hline Qz & + & + & + & + & + & - & + \\
\hline $\mathrm{Pl}$ & + & + & + & + & + & + & + \\
\hline Kfs & - & + & + & + & + & - & - \\
\hline $\mathrm{Bt}$ & - & + & + & + & + & + & - \\
\hline Mus & - & - & + & + & + & - & - \\
\hline Grt & - & - & - & - & - & - & - \\
\hline Ep & - & + & - & + & - & + & - \\
\hline $\mathrm{Hb}$ & + & + & - & - & - & + & + \\
\hline $\mathrm{Cm}$ & - & - & - & - & - & - & - \\
\hline Texture & G & $\mathrm{L}$ & $\mathrm{L}$ & $\mathrm{L}$ & L & $\mathrm{L}, \mathrm{N}$ & $\mathrm{N}$ \\
\hline \multicolumn{8}{|l|}{ Grain size (mm) } \\
\hline Variation & $0.05-0.4$ & $0.1-0.7$ & $0.1-1.0$ & $0.02-0.1$ & $0.02-0.2$ & $0.03-0.3$ & $0.05-0.3$ \\
\hline Most frequent size & 0.2 & 0.2 & 0.2 & 0.03 & 0.1 & 0.07 & 0.1 \\
\hline
\end{tabular}

Localities: M, Mizoguchi; KK, Katakai River basin; KB, Kurobe River basin. Minerals: Qz, quartz; Pl, plagioclas; Kfs, potash feldspar; Bt, biotite; Mus, muscovite; Grt, garnet; Ep, epidote; Hb, hornblende; Cm, cummingtonite; + and - indicates presence and absence, respectively. Textures: L, lepidoblastic, by biotite or muscovite; N, nematoblastic, by amphibole; $\mathrm{P}$, porphyroblastic, by garnet; G, granoblastic.

features of the basic rocks suggest that they originated as basaltic magma.

Petrographic characteristics of individual specimens from the Mizoguchi area and the Unazuki schists (described later) are given in Table 1.

\section{Mineral chemistry and equilibration temperature}

The formation conditions of the Mizoguchi metamorphic rocks were estimated by analyzing chemical compositions of coexisting biotite and garnet in metapelite, and hornblende and plagioclase in metabasite using an electron probe micro-analyzer, JEOL JXA-733, at Okayama University, with an accelerating voltage of 15
$\mathrm{kV}$ and a sample current of $1.0^{-2.0 \times 10^{-8}}$ A. Standards used were natural or synthetic oxides and silicates. Matrix corrections followed the procedures of Bence and Albee (1968) with alpha factors of Nakamura and Kushiro (1970). Representative analyses are listed in Table 2.

Garnet has a pyrope component of approximately $15 \mathrm{~mol} \%$ in the core and $12 \mathrm{~mol} \%$ at the rim. Biotite adjacent to the garnet has $\mathrm{Mg} /(\mathrm{Mg}+\mathrm{Fe})$ ratios of $0.37-$ 0.40. Hornblende belongs to the magnesio-hornblende group, according to the Leake's (1978) classification. The rims tend to be richer in $\mathrm{Si}$ and poorer in $\mathrm{Ti}$ and $\mathrm{Al}$ than the cores (Table 2). Plagioclase coexisting with the hornblende has a $\mathrm{Na} /(\mathrm{Na}+\mathrm{Ca})$ ratio of $0.43-0.64$. 
Table 2. Representative microprobe analyses of metamorphic minerals from Mizoguchi

\begin{tabular}{|c|c|c|c|c|c|c|c|c|c|c|}
\hline $\begin{array}{l}\text { Specimen No. } \\
\text { Phase }\end{array}$ & $\begin{array}{r}840704 \\
\text { Grt core }\end{array}$ & $\begin{array}{l}840704 \\
\text { Grt rim }\end{array}$ & $\begin{array}{r}840704 \\
\mathrm{Bt}\end{array}$ & $\begin{array}{l}852805 \\
\text { Grt core }\end{array}$ & $\begin{array}{l}852805 \\
\text { Grt rim }\end{array}$ & $\begin{array}{r}852805 \\
\mathrm{Bt}\end{array}$ & $\begin{array}{r}840708 \\
\text { Am core }\end{array}$ & $\begin{array}{l}840708 \\
\text { Am rim }\end{array}$ & $\begin{array}{r}852806 \\
\text { Am core }\end{array}$ & $\begin{array}{l}852806 \\
\text { Am rim }\end{array}$ \\
\hline$\overline{\mathrm{SiO}_{2}}$ & 37.15 & 36.84 & 32.39 & 37.42 & 37.07 & 34.84 & 47.95 & 48.27 & 49.62 & 51.00 \\
\hline $\mathrm{TiO}_{2}$ & 0.06 & 0.04 & 1.85 & 0.04 & 0.01 & 1.51 & 1.07 & 0.96 & 1.10 & 0.88 \\
\hline $\mathrm{Al}_{2} \mathrm{O}_{3}$ & 20.99 & 20.53 & 18.34 & 20.97 & 20.80 & 19.31 & 6.56 & 6.20 & 6.50 & 5.67 \\
\hline $\mathrm{FeO}^{*}$ & 34.19 & 34.46 & 24.80 & 33.69 & 34.70 & 21.99 & 14.32 & 14.11 & 11.33 & 10.81 \\
\hline $\mathrm{MnO}$ & 2.23 & 2.83 & 0.26 & 2.76 & 3.15 & 0.12 & 0.38 & 0.36 & 0.33 & 0.34 \\
\hline $\mathrm{MgO}$ & 3.78 & 2.97 & 8.85 & 3.71 & 2.92 & 7.67 & 13.62 & 13.61 & 15.72 & 16.10 \\
\hline $\mathrm{CaO}$ & 1.25 & 1.54 & 0.20 & 1.46 & 1.41 & 0.05 & 12.15 & 12.31 & 11.92 & 11.85 \\
\hline $\mathrm{Na}_{2} \mathrm{O}$ & nd & nd & 0.08 & nd & nd & 0.09 & 0.97 & 0.94 & 0.75 & 0.61 \\
\hline $\mathrm{K}_{2} \mathrm{O}$ & nd & nd & 7.45 & nd & nd & 8.91 & 0.40 & 0.38 & 0.34 & 0.23 \\
\hline Total & 99.65 & 99.21 & 94.22 & 100.05 & 100.06 & 94.49 & 97.42 & 97.14 & 97.61 & 97.49 \\
\hline Cations $/ \mathrm{O}=$ & 12.000 & 12.000 & 22.000 & 12.000 & 12.000 & 22.000 & 23.000 & 23.000 & 23.000 & 23.000 \\
\hline $\mathrm{Si}$ & 2.993 & 3.001 & 5.120 & 3.002 & 2.996 & 5.404 & 7.073 & 7.131 & 7.165 & 7.326 \\
\hline $\mathrm{Ti}$ & 0.004 & 0.002 & 0.220 & 0.002 & 0.001 & 0.176 & 0.119 & 0.107 & 0.119 & 0.095 \\
\hline $\mathrm{Al}$ & 1.993 & 1.971 & 3.417 & 1.983 & 1.981 & 3.530 & 1.140 & 1.080 & 1.106 & 0.960 \\
\hline $\mathrm{Fe}$ & 2.303 & 2.347 & 3.278 & 2.260 & 2.345 & 2.852 & 1.767 & 1.743 & 1.368 & 1.299 \\
\hline $\mathrm{Mn}$ & 0.152 & 0.195 & 0.035 & 0.188 & 0.216 & 0.016 & 0.047 & 0.045 & 0.040 & 0.041 \\
\hline $\mathrm{Mg}$ & 0.454 & 0.361 & 2.085 & 0.444 & 0.352 & 1.773 & 2.995 & 2.997 & 3.384 & 3.448 \\
\hline $\mathrm{Ca}$ & 0.108 & 0.134 & 0.034 & 0.125 & 0.122 & 0.008 & 1.920 & 1.949 & 1.844 & 1.824 \\
\hline $\mathrm{Na}$ & nd & nd & 0.025 & nd & nd & 0.027 & 0.277 & 0.269 & 0.210 & 0.170 \\
\hline $\mathrm{K}$ & nd & nd & 1.502 & nd & nd & 1.763 & 0.075 & 0.072 & 0.063 & 0.042 \\
\hline Total & 8.007 & 8.011 & 15.715 & 8.004 & 8.013 & 15.550 & 15.414 & 15.393 & 15.299 & 15.205 \\
\hline $\mathrm{Ab}$ & nd & nd & nd & 0.58 & 0.58 & 0.58 & 0.60 & 0.60 & 0.60 & 0.60 \\
\hline
\end{tabular}

*total iron as $\mathrm{FeO}$; nd, not determined; Grt, garnet; Bt, biotite; Am, amphibole; $\mathrm{Ab}, \mathrm{Na} /(\mathrm{Na}+\mathrm{Ca})$ of coexisting plagioclase.

Equilibration temperatures of minerals were estimated using the geothermometers of Dasgupta et al. (1991) and Holland and Blundy (1994), for pressures ranging from 0.4 to $0.7 \mathrm{GPa}$, the possible values of pressure during the Hida and Oki metamorphism (Suzuki et al., 1989; Sawada et al., 2000). The results give temperatures of $550-660^{\circ} \mathrm{C}$ (ca. $610^{\circ} \mathrm{C}$ on average) between garnet (rim) and biotite, and $570-750^{\circ} \mathrm{C}$ (ca. $680^{\circ} \mathrm{C}$ on average) between hornblende (rim) and plagioclase. The faint compositional zoning of garnet and hornblende makes the estimated temperatures higher to some extent at the cores than the rims, suggesting the peak conditions of metamorphism correspond to the amphibolite or granulite facies as seen in the Hida terrane (Hiroi, 1983; Suzuki et al., 1989).

\section{Whole-rock chemistry}

Chemical compositions of eight metamorphic rocks from the Mizoguchi area were analyzed at Activation Laboratories Ltd., Canada, using ICP-OES for major elements and Sc, and ICP-MS for other elements. Results are listed in Table 3 and compared with the published data of equivalent rocks from the Hida terrane in Figures 2, 3 and 4. Chemical analyses of biotite gneisses and intercalated hornblende gneisses from the Hida gneiss region are available from the literature (Naito, 1993; Jin and Ishiwatari, 1997; Arakawa et al., 2000). In contrast very few chemical data of Unazuki schists have been published. Although Hiroi (1984) has analyzed a number of ferruginous pelitic rocks of laterite origin, they are unsuitable for comparison in this study because of their unusual compositions. A comparison between rocks of similar lithology is more meaningful, and we, therefore, collected several specimens of biotite- and hornblende-schists from the Kurobe and Katakai River basins where alternating basic, pelitic, psammitic and quartzo-feldspathic schists are exposed (Fig. 1c; Hiroi, 1978; Suwa, 1979). The geochemical data of the Unazuki schists we collected are listed in Table 4. Their petrographic characteristics (Table 1) are consistent with the descriptions by Hiroi (1978) and Suwa (1979). Besides the specimens in Tables 1 and 4 there are also schists composed of alternating basic and pelitic laminae $1-2 \mathrm{~mm}$ thick, but we do not consider them here because of their inhomogeneity.

Figure 2 shows that metapelite and metabasite from the Mizoguchi area are similar in major element compositions to biotite-schist or -gneiss and hornblende-schist 
Table 3. Chemical compositions of metamorphic rocks from Mizoguchi

\begin{tabular}{|c|c|c|c|c|c|c|c|c|}
\hline $\begin{array}{l}\text { Specimen No. } \\
\text { Rock Type }\end{array}$ & $\begin{array}{r}840703 \\
\text { pelitic }\end{array}$ & $\begin{array}{r}840704 \\
\text { pelitic }\end{array}$ & $\begin{array}{r}840701 \\
\text { pelitic }\end{array}$ & $\begin{array}{r}852801 \\
\text { pelitic }\end{array}$ & $\begin{array}{r}852802 \\
\text { pelitic }\end{array}$ & $\begin{array}{r}990905 \\
\text { basic }\end{array}$ & $\begin{array}{r}990906 \\
\text { basic }\end{array}$ & $\begin{array}{r}990914 \\
\text { basic }\end{array}$ \\
\hline $\mathrm{SiO}_{2}$ (wt.\%) & 58.87 & 57.80 & 60.06 & 59.36 & 62.99 & 51.36 & 51.71 & 50.65 \\
\hline $\mathrm{TiO}_{2}$ & 1.13 & 1.09 & 1.16 & 1.15 & 0.93 & 1.26 & 1.06 & 1.08 \\
\hline $\mathrm{Al}_{2} \mathrm{O}_{3}$ & 16.86 & 18.25 & 15.74 & 16.86 & 16.30 & 16.90 & 16.91 & 16.88 \\
\hline $\mathrm{FeO}^{*}$ & 8.72 & 7.53 & 9.09 & 8.05 & 5.77 & 9.11 & 9.92 & 10.93 \\
\hline $\mathrm{MnO}$ & 0.17 & 0.24 & 0.20 & 0.15 & 0.08 & 0.22 & 0.24 & 0.26 \\
\hline $\mathrm{MgO}$ & 2.48 & 1.91 & 3.29 & 2.44 & 2.06 & 5.65 & 4.98 & 5.10 \\
\hline $\mathrm{CaO}$ & 4.32 & 4.49 & 4.75 & 4.52 & 4.14 & 7.98 & 7.36 & 7.27 \\
\hline $\mathrm{Na}_{2} \mathrm{O}$ & 3.73 & 3.61 & 3.61 & 3.56 & 3.46 & 3.80 & 3.55 & 3.69 \\
\hline $\mathrm{K}_{2} \mathrm{O}$ & 2.05 & 2.91 & 0.51 & 1.90 & 1.88 & 0.69 & 0.64 & 0.85 \\
\hline $\mathrm{P}_{2} \mathrm{O}_{5}$ & 0.20 & 0.69 & 0.22 & 0.20 & 0.18 & 0.16 & 0.11 & 0.11 \\
\hline LOI & 0.95 & 1.27 & 0.96 & 1.08 & 1.90 & 1.02 & 0.94 & 0.90 \\
\hline Total & 99.48 & 99.79 & 99.59 & 100.16 & 100.32 & 99.14 & 98.52 & 98.94 \\
\hline $\mathrm{Sc}(\mathrm{ppm})$ & 32 & 25 & 29 & 27 & 23 & 35 & 44 & 44 \\
\hline V & 135 & 90 & 217 & 141 & 117 & 287 & 342 & 320 \\
\hline $\mathrm{Cr}$ & 19 & 10 & 19 & 90 & 48 & 87 & 28 & 43 \\
\hline Co & 16 & 8.4 & 17 & 15 & 12 & 25 & 18 & 18 \\
\hline $\mathrm{Ni}$ & 11 & $<15$ & $<15$ & 76 & $<15$ & $<15$ & $<15$ & $<15$ \\
\hline $\mathrm{Cu}$ & 27 & $<10$ & 17 & 20 & 21 & 15 & $<10$ & $<10$ \\
\hline $\mathrm{Zn}$ & 141 & 113 & 127 & 104 & 94 & 75 & 59 & 57 \\
\hline $\mathrm{Rb}$ & 54 & 93 & 15 & 44 & 50 & 25 & 24 & 29 \\
\hline $\mathrm{Sr}$ & 211 & 250 & 268 & 219 & 186 & 255 & 238 & 233 \\
\hline $\mathrm{Y}$ & 46 & 60 & 33 & 39 & 48 & 30 & 25 & 24 \\
\hline $\mathrm{Zr}$ & 210 & 182 & 143 & 193 & 218 & 92 & 30 & 26 \\
\hline $\mathrm{Nb}$ & 13 & 10 & 3 & 4 & 5 & 2 & 1 & $<1$ \\
\hline $\mathrm{Ba}$ & 280 & 564 & 230 & 318 & 230 & 105 & 86 & 87 \\
\hline $\mathrm{La}$ & 16.0 & 16.0 & 9.6 & 13.1 & 15.1 & 3.9 & 2.3 & 1.9 \\
\hline $\mathrm{Ce}$ & 36.0 & 40.0 & 23.0 & 30.6 & 36.0 & 11.4 & 6.6 & 5.5 \\
\hline $\operatorname{Pr}$ & 4.59 & 5.06 & 3.28 & 4.52 & 5.39 & 1.94 & 1.15 & 1.01 \\
\hline $\mathrm{Nd}$ & 22.0 & 24.0 & 15.0 & 20.3 & 24.4 & 9.8 & 6.1 & 5.6 \\
\hline $\mathrm{Sm}$ & 5.8 & 7.1 & 4.5 & 5.2 & 6.4 & 3.2 & 2.3 & 2.1 \\
\hline $\mathrm{Eu}$ & 1.66 & 1.31 & 1.50 & 1.77 & 1.51 & 1.37 & 1.00 & 0.96 \\
\hline Gd & 5.7 & 7.7 & 5.1 & 6.4 & 7.7 & 4.4 & 3.4 & 3.2 \\
\hline $\mathrm{Tb}$ & 1.2 & 1.6 & 1.0 & 1.1 & 1.3 & 0.8 & 0.7 & 0.6 \\
\hline Dy & 7.8 & 9.5 & 5.9 & 6.7 & 7.9 & 5.1 & 4.2 & 4.1 \\
\hline Ho & 1.6 & 1.9 & 1.3 & 1.4 & 1.7 & 1.1 & 0.9 & 0.9 \\
\hline $\mathrm{Er}$ & 5.1 & 5.8 & 3.6 & 4.3 & 5.0 & 3.4 & 2.7 & 2.7 \\
\hline $\mathrm{Tm}$ & 0.86 & 0.90 & 0.56 & 0.61 & 0.70 & 0.47 & 0.40 & 0.39 \\
\hline $\mathrm{Yb}$ & 5.7 & 5.7 & 3.6 & 4.0 & 4.5 & 3.2 & 2.7 & 2.6 \\
\hline $\mathrm{Lu}$ & 0.84 & 0.83 & 0.54 & 0.60 & 0.67 & 0.46 & 0.39 & 0.38 \\
\hline Hf & 5.8 & 4.9 & 3.4 & 5.3 & 6.0 & 2.6 & 1.1 & 1.0 \\
\hline $\mathrm{Ta}$ & 0.6 & 0.5 & 0.1 & 0.3 & 0.3 & 0.1 & $<0.1$ & $<0.1$ \\
\hline $\mathrm{Pb}$ & 14 & 16 & 15 & 13 & $<5$ & $<5$ & 15 & 8 \\
\hline Th & 2.9 & 1.9 & 1.2 & 2.6 & 3.8 & 0.3 & 0.2 & 0.2 \\
\hline $\mathrm{U}$ & 0.8 & 0.7 & 0.3 & 0.6 & 1.1 & 0.1 & 0.2 & 0.1 \\
\hline $\mathrm{A} / \mathrm{CNK}$ & 1.04 & 1.06 & 1.04 & 1.05 & 1.07 & 0.79 & 0.85 & 0.84 \\
\hline $\mathrm{K} / \mathrm{NK}$ & 0.27 & 0.35 & 0.09 & 0.26 & 0.26 & 0.11 & 0.11 & 0.13 \\
\hline
\end{tabular}

*total iron as $\mathrm{FeO} ; \mathrm{A} / \mathrm{CNK}, \mathrm{Al}_{2} \mathrm{O}_{3} /\left(\mathrm{CaO}+\mathrm{Na}_{2} \mathrm{O}+\mathrm{K}_{2} \mathrm{O}\right)$ mole ratio; $\mathrm{K} / \mathrm{NK}, \mathrm{K}_{2} \mathrm{O} /\left(\mathrm{Na}_{2} \mathrm{O}+\mathrm{K}_{2} \mathrm{O}\right)$ mole ratio.

or - gneiss from the Hida terrane, respectively. Both the metapelite from the Mizoguchi area and biotite schist from Unazuki have $\mathrm{Al}_{2} \mathrm{O}_{3} /\left(\mathrm{CaO}+\mathrm{Na}_{2} \mathrm{O}+\mathrm{K}_{2} \mathrm{O}\right)$ mole ratios of ca. 1.0 and $\mathrm{K}_{2} \mathrm{O} /\left(\mathrm{Na}_{2} \mathrm{O}+\mathrm{K}_{2} \mathrm{O}\right)$ mol ratios of
0.1- 0.4, which correspond to the Low-K group of Hida gneisses of Jin and Ishiwatari (1997).

Despite the similarity in major elements, trace element analyses reveal some clear differences between 

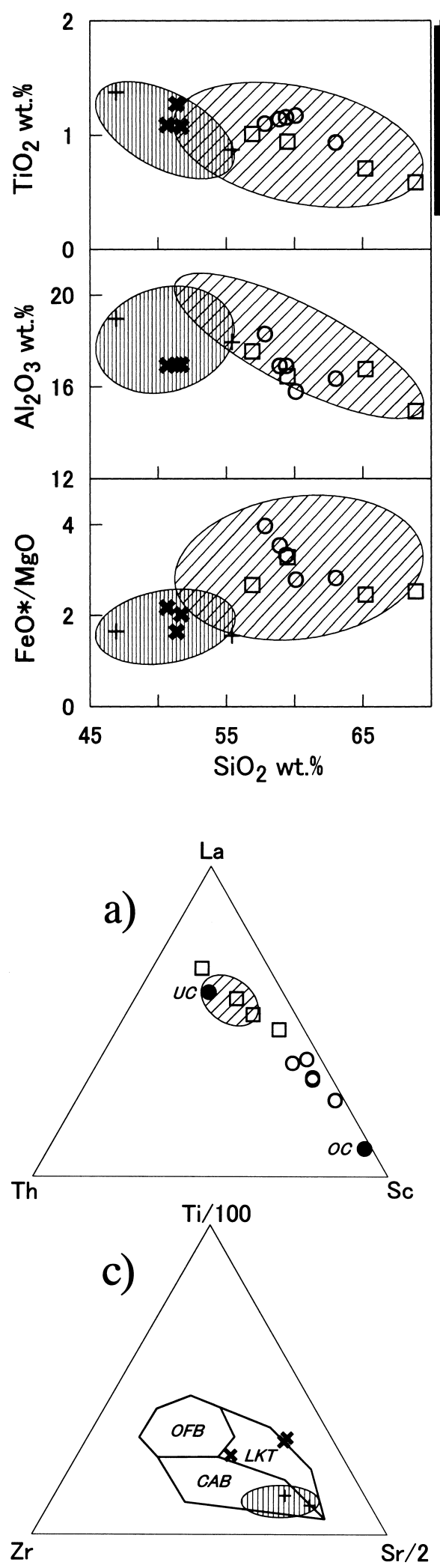

$\mathrm{Sr} / 2 \quad 0.25 \mathrm{Zr}$
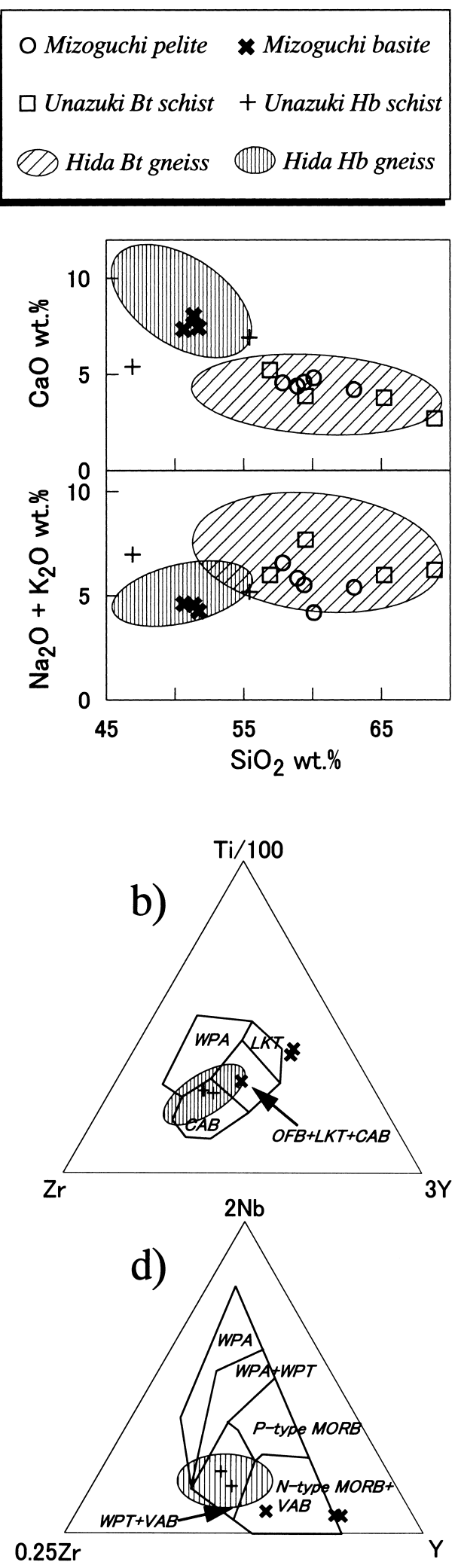

Figure 2. Variations of major oxides vs. $\mathrm{SiO}_{2}$ in metamorphic rocks from Mizoguchi and the Unazuki schist zone. Hatched fields represent the compositions of hornblende- ${ }^{-}$and biotitegneisses from the Hida gneiss region (after Naito, 1993; Jin and Ishiwatari, 1997; Arakawa, 2000).

Figure 3. $\mathrm{La}-\mathrm{Th}-\mathrm{Sc}$ ratios in pelitic rocks (a) and trace element discrimination diagrams for basaltic rocks $(b-d)$ after Pearce and Cann (1973) and Meschede (1986). UC, upper continental crust; OC, average oceanic crust; WPB, withinplate basalt; LKT, low-potassium tholeiite; $\mathrm{CAB}$, calcalkali basalt; OFB, ocean-floor basalt; WPA, within-plate alkali basalt; WPT, withinplate tholeiite; MORB, midocean ridge basalt; VAB, volcanic arc basalt. Hatched fields and symbols are as in Figure 2. the rocks of the Hida terrane and the Mizoguchi area. The trace element analyses also emphasize similarities between the Hida gneisses and Unazuki schists. In the
La-Th-Sc diagram (Fig. 3a), the Hida gneisses and Unazuki schists show correspondence to the average composition of upper continental crust, whereas the 


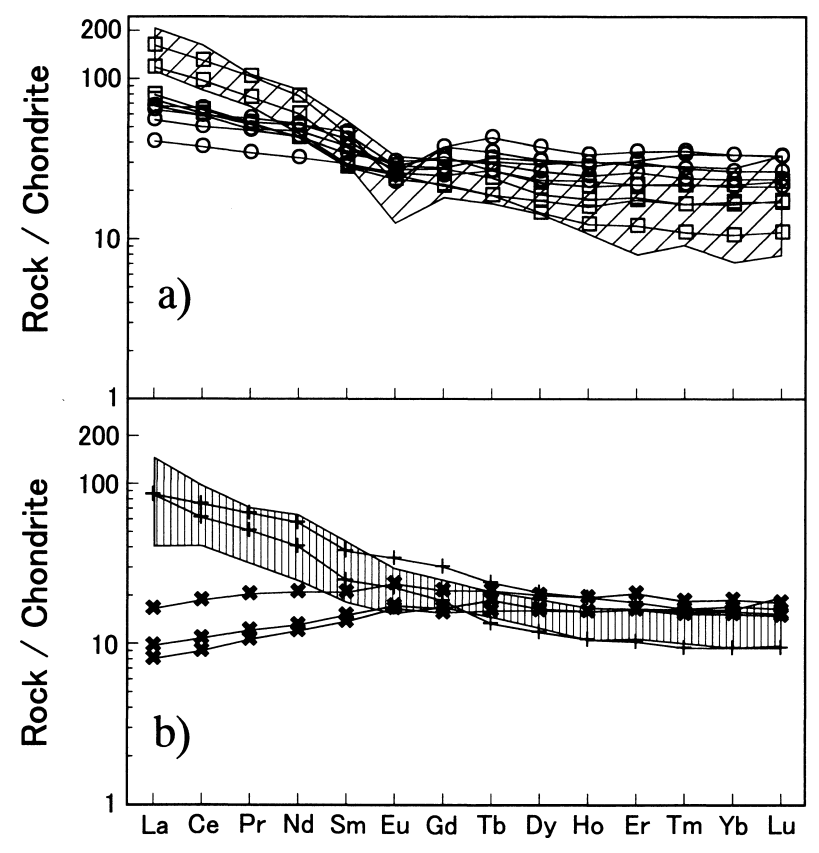

Figure 4. Concentration patterns of REE in pelitic rocks (a) and basic rocks (b) normalized with the values of $\mathrm{Cl}$ chondrite (Sun and McDonough, 1989). Hatched fields and symbols are as in Figure 2.

Mizoguchi metapelites are relatively rich in Sc, suggesting the addition of oceanic crustal components to upper continental materials (Taylor and McLennan, 1985). In ternary discrimination diagrams for basaltic rocks (Figs. 3b-d), metabasites from the Mizoguchi area plot in the fields of arc tholeiites or mid ocean ridge basalts (MORBs), unlike the Hida schists and gneisses which plot in the fields of calc-alkaline basalts.

The concentration patterns of REE make the distinction more clear between the Mizoguchi and Hida metamorphic rocks. Compared to the Hida biotite -schist or -gneiss, the Mizoguchi metapelite is enriched in heavy REEs and depleted in light REEs, showing gently inclined patterns (Fig. 4a), similar to those of fore -arc turbidites (McLennan, 1989). However, two specimens of the Unazuki biotite schist (nos. 5 and 6), which were collected at outcrops of Kitamatadani, a mountain stream in the Katakai River basin, are not so rich in light LEEs as the other Hida biotite-schists and -gneisses. Because the outcrops are in the area of alternating biotite $^{-}$and hornblende-schist (see the route map by Suwa, 1979), it is possible that the chemical compositions of the biotite schists show the effect of mechanical mixing of basic rocks during sedimentation.

The Mizoguchi metabasites are relatively depleted in light REEs contrary to the Hida hornblende-schists and -gneisses exhibiting light REE enrichment patterns (Fig. 4b). The type of REE pattern shown by the
Mizoguchi metabasites is typical for N-MORBs or forearc tholeiites (Sun and McDonough, 1989; Hickey and Frey, 1982; Tatsumi, 1995). Furthermore, because the Mizoguchi metabasites are much richer in LIL elements than N-MORBs (Fig. 5), it is suggested that they originated in an island arc environment (Pearce, 1983).

Based on the above geochemical characterization, we consider the Mizoguchi metamorphic rocks originally formed in the fore-arc region of an immature, oceanic island arc.

\section{Discussion}

The Unazuki biotite schists and hornblende schists analyzed in this study have almost the same compositions as the Hida biotite gneisses and hornblende gneisses, respectively. They are much more widely distributed in the Unazuki schist zone than the lateritic schists (Hiroi, 1978; Suwa, 1979); in other words, the extremely aluminous rocks appear to be unusual even in this zone, though they are important as hosts to minerals that can be used to characterize the $\mathrm{P}-\mathrm{T}$ conditions of regional metamorphism. It follows that the Unazuki schist zone and Hida gneiss region are essentially identical in their principal chemical characteristics. These data are in accord with the idea proposed by several workers that the tectonic setting was the same throughout the Hida terrane. The general consensus is that the Hida terrane formed in a rift zone at a continental margin, marginal sea or continental island arc on the basis of the predominance of calcareous sediments and the bimodal compositions of volcanic rocks (Sohma et al., 1990; Naito, 1993; Komatsu et al., 1993; Arakawa et al., 2000).

In contrast, the rocks of the Mizoguchi area are clearly distinct from the Hida terrane both in the chemical characteristics of pelitic and basic rocks as well as the absence of metamorphosed laterite, limestone and acid volcanic rock. As mentioned above, the Mizoguchi metamorphic rocks exhibit geochemical characteristics suggesting they formed in the fore-arc region of an oceanic island arc. This tectonic setting is clearly different from that of the Hida terrane, and therefore, we consider that the Mizoguchi area and Hida terrane are geologically discontinuous.

Our conclusion is in contrast to the earlier work of Ishiga et al. (1989) who regarded the Mizoguchi metamorphic rocks as the exposures of a western continuation of the Hida terrane based on similarities in mineralogy, metamorphic temperature conditions and radiometric ages. In fact, however, even these features are not entirely compatible between the two regions. The Mizoguchi metamorphics are comparable to the 
Table 4. Chemical compositions of biotite- and hornblende-schists from the Unazuki schist zone

\begin{tabular}{|c|c|c|c|c|c|c|}
\hline $\begin{array}{l}\text { Specimen No. } \\
\text { Rock Type }\end{array}$ & $\begin{array}{r}5 \\
\text { Bt schist }\end{array}$ & $\begin{array}{r}6 \\
\text { Bt schist }\end{array}$ & $\begin{array}{r}11 \\
\text { Bt schist }\end{array}$ & $\begin{array}{r}19 \\
\text { Bt schist }\end{array}$ & $\begin{array}{r}14 \\
\text { Hb schist }\end{array}$ & $\begin{array}{r}24 \\
\text { Hb schist }\end{array}$ \\
\hline $\mathrm{SiO}_{2}$ (wt.\%) & 56.86 & 65.16 & 68.82 & 59.44 & 46.97 & 55.47 \\
\hline $\mathrm{TiO}_{2}$ & 1.00 & 0.70 & 0.58 & 0.93 & 1.37 & 0.87 \\
\hline $\mathrm{Al}_{2} \mathrm{O}_{3}$ & 17.50 & 16.73 & 14.9 & 16.41 & 18.93 & 17.91 \\
\hline $\mathrm{FeO}^{*}$ & 7.65 & 3.85 & 2.83 & 5.70 & 9.85 & 6.06 \\
\hline $\mathrm{MnO}$ & 0.25 & 0.07 & 0.07 & 0.13 & 0.15 & 0.14 \\
\hline $\mathrm{MgO}$ & 2.89 & 1.58 & 1.13 & 1.75 & 6.05 & 3.96 \\
\hline $\mathrm{CaO}$ & 5.16 & 3.73 & 2.65 & 3.82 & 5.34 & 6.87 \\
\hline $\mathrm{Na}_{2} \mathrm{O}$ & 3.77 & 4.12 & 3.34 & 3.61 & 3.65 & 3.77 \\
\hline $\mathrm{K}_{2} \mathrm{O}$ & 2.18 & 1.82 & 2.84 & 4.03 & 3.29 & 1.37 \\
\hline $\mathrm{P}_{2} \mathrm{O}_{5}$ & 0.35 & 0.15 & 0.15 & 0.22 & 0.40 & 0.25 \\
\hline LOI & 1.82 & 1.26 & 1.25 & 2.07 & 1.56 & 1.43 \\
\hline Total & 99.43 & 99.17 & 98.56 & 98.11 & 97.55 & 98.10 \\
\hline $\mathrm{Sc}(\mathrm{ppm})$ & 17 & 13 & 8 & 14 & 26 & 19 \\
\hline V & 193 & 86 & 44 & 130 & 259 & 193 \\
\hline $\mathrm{Cr}$ & 41 & 57 & 73 & 91 & 53 & 46 \\
\hline Co & 19 & 9 & 3 & 15 & 30 & 17 \\
\hline $\mathrm{Ni}$ & 22 & $<15$ & $<15$ & $<15$ & 29 & 15 \\
\hline $\mathrm{Cu}$ & 18 & 19 & $<10$ & 33 & 31 & 12 \\
\hline $\mathrm{Zn}$ & 143 & 32 & $<30$ & 98 & 101 & 39 \\
\hline $\mathrm{Rb}$ & 76 & 66 & 68 & 113 & 93 & 34 \\
\hline $\mathrm{Sr}$ & 641 & 394 & 542 & 366 & 846 & 809 \\
\hline $\mathrm{Y}$ & 21 & 27 & 35 & 29 & 31 & 17 \\
\hline $\mathrm{Zr}$ & 120 & 163 & 350 & 235 & 146 & 94 \\
\hline $\mathrm{Nb}$ & 6 & 6 & 14 & 11 & 6 & 5 \\
\hline $\mathrm{Ba}$ & 950 & 509 & 471 & 500 & 465 & 487 \\
\hline $\mathrm{La}$ & 17.5 & 18.8 & 38.3 & 27.9 & 20.3 & 20.2 \\
\hline $\mathrm{Ce}$ & 37.0 & 39.0 & 79.3 & 59.4 & 45.7 & 37.6 \\
\hline $\operatorname{Pr}$ & 4.93 & 5.03 & 9.81 & 7.26 & 6.21 & 4.83 \\
\hline $\mathrm{Nd}$ & 20.2 & 20.0 & 36.3 & 28.1 & 26.6 & 18.9 \\
\hline $\mathrm{Sm}$ & 4.4 & 4.3 & 6.9 & 5.7 & 5.8 & 3.8 \\
\hline $\mathrm{Eu}$ & 1.46 & 1.37 & 1.66 & 1.57 & 1.98 & 1.30 \\
\hline $\mathrm{Gd}$ & 4.4 & 4.5 & 6.7 & 5.6 & 6.2 & 3.8 \\
\hline $\mathrm{Tb}$ & 0.7 & 0.7 & 1.0 & 0.9 & 0.9 & 0.5 \\
\hline Dy & 3.7 & 4.4 & 5.7 & 4.8 & 5.3 & 3.0 \\
\hline Ho & 0.7 & 0.9 & 1.2 & 1.0 & 1.1 & 0.6 \\
\hline $\mathrm{Er}$ & 2.0 & 2.9 & 3.6 & 3.0 & 3.0 & 1.7 \\
\hline $\mathrm{Tm}$ & 0.28 & 0.42 & 0.55 & 0.42 & 0.42 & 0.24 \\
\hline $\mathrm{Yb}$ & 1.8 & 2.8 & 3.7 & 2.9 & 2.9 & 1.6 \\
\hline $\mathrm{Lu}$ & 0.28 & 0.44 & 0.58 & 0.43 & 0.42 & 0.24 \\
\hline Hf & 3.1 & 4.4 & 8.7 & 6.0 & 3.8 & 2.5 \\
\hline Ta & 0.3 & 0.4 & 0.9 & 0.6 & 0.3 & 0.3 \\
\hline $\mathrm{Pb}$ & 52 & 29 & 5 & 27 & 15 & $<5$ \\
\hline Th & 2.8 & 4.5 & 11.1 & 7.1 & 2.7 & 3.9 \\
\hline $\mathrm{U}$ & 0.9 & 1.7 & 4.3 & 2.5 & 0.8 & 1.3 \\
\hline $\mathrm{A} / \mathrm{CNK}$ & 0.98 & 1.08 & 1.11 & 0.95 & 0.98 & 0.89 \\
\hline $\mathrm{K} / \mathrm{NK}$ & 0.28 & 0.23 & 0.36 & 0.42 & 0.37 & 0.19 \\
\hline
\end{tabular}

*total iron as $\mathrm{FeO} ; \mathrm{A} / \mathrm{CNK}, \mathrm{Al}_{2} \mathrm{O}_{3} /\left(\mathrm{CaO}+\mathrm{Na}_{2} \mathrm{O}+\mathrm{K}_{2} \mathrm{O}\right)$ mole ratio; $\mathrm{K} / \mathrm{NK}, \mathrm{K}_{2} \mathrm{O} /\left(\mathrm{Na}_{2} \mathrm{O}+\mathrm{K}_{2} \mathrm{O}\right)$ mole ratio.

Unazuki schists rather than Hida gneisses with respect to grain size, but show higher equilibration temperatures and lack mineral associations indicative of medium $\mathrm{P} / \mathrm{T}$ type metamorphism (see Hiroi, 1978, 1983). Ishiga et al. (1989) obtained a radiometric age of ca. $185 \mathrm{Ma}$ for a sample of Mizoguchi metabasite using the $\mathrm{Rb}-\mathrm{Sr}$ whole rock-mineral isochron method, whereas the regional metamorphism of the Hida terrane took place 


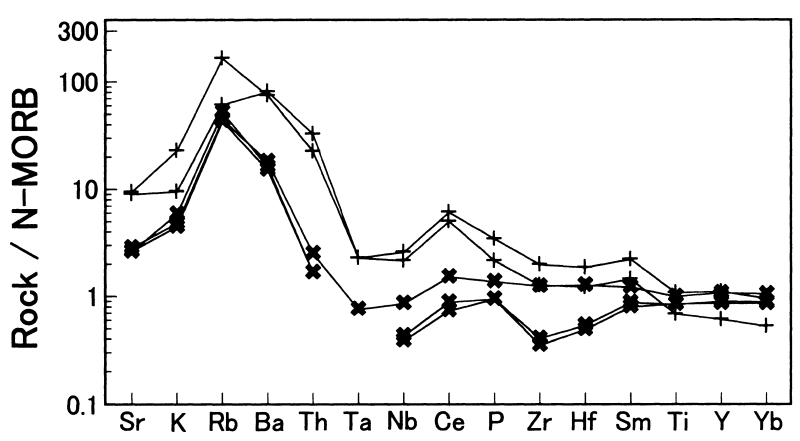

Figure 5. Concentration patterns of trace elements in metamorphic rocks from Mizoguchi and the Unazuki schist zone normalized with the values of N-type MORB (Sun and McDonough, 1989). Symbols are as in Figure 2.

at 230-250 Ma or earlier (e.g., Hiroi, 1978; Suzuki et al., 1989). The age of the Mizoguchi metabasite corresponds to the timing of intrusion of Funatsu granites, which caused the contact metamorphism of surrounding rocks in the Hida terrane (Shibata et al., 1970; Suzuki et al., 1989; Ota and Itaya, 1989; Sohma et al., 1990). Because the Mizoguchi metamorphic rocks occur in close association with Jurassic granitoids (Ishiga et al., 1989; Miyamoto et al., 2000), it is possible that the age of $185 \mathrm{Ma}$ indicates the timing of contact metamorphism by the granitoids. Unlike the Unazuki schists adjacent to the Funatsu granites, however, the Mizoguchi metamorphic rocks do not show evidence for polymetamorphism. Retrograde products formed after the peak amphibolite facies metamorphism are observed in the Mizoguchi metamorphic rocks; however, they are only of local importance and the secondary overprint was low-grade. We, therefore, consider this event to have had no significant effect on the age determination using the $\mathrm{Rb}-\mathrm{Sr}$ internal isochron method. It is debatable whether the age indicates the timing of regional metamorphism or contact metamorphism, but in any case there is no evidence for regional, medium- or high $-\mathrm{P} / \mathrm{T}$ metamorphism before the Jurassic in the Mizoguchi area.

Oki-Dogo has long been widely accepted as the western continuation of the Hida terrane because of the similarities in the grade and age of metamorphic rocks (Ohta, 1963; Shibata and Nozawa, 1966; Hayase and Ishizaka, 1967; Hoshino, 1979; Kobayashi et al., 1980; Suzuki and Adachi, 1994; Yamashita and Yanagi, 1994; Dallmeyer and Takasu, 1998; Sawada et al., 2000). On the other hand, since Komatsu et al. (1985) suggested the Hida terrane is a nappe thrust over the Paleozoic accretionary complexes of Southwest Japan, several workers have distinguished the Oki metamorphic complex from the Hida terrane, based on paleogeographical considerations and differences in whole-rock compositions between the Oki and Hida gneisses (Sohma et al., 1990; Isozaki and Maruyama, 1991; Sohma and Kunugiza, 1993; Jin and Ishiwatari, 1997; Arakawa et al, 2001). Indeed, the rarity of calcareous rocks in Oki -Dogo suggests a provenance distinct from the Hida terrane, but we should examine the degree of redistribution of elements when we compare the compositions of common types of rocks, because migmatization has significantly affected the Oki metamorphic complex (Kobayashi et al, 1980). In addition, according to Arakawa et al. (2001), the metabasites of the Oki-Dogo area appear to have different geochemical characteristics from those of the Mizoguchi area, but their considerable variation in chemical composition and mode of occurrence do not yet allow us to obtain conclusive evidence regarding the possible differences in their tectonic settings. Further investigation of the geochemical characteristics of the Oki-Dogo and Mizoguchi areas would help clarify their geological relationship.

\section{Conclusions}

The metamorphic rocks of the Mizoguchi area were originally formed in the fore-arc region of an oceanic island arc, in contrast to those of the Hida terrane, which show affinities with rocks from continental margins or continental island arcs. The difference in the tectonic setting of rock formation suggests the geological discontinuity between the Mizoguchi area and the Hida terrane.

\section{Acknowledgements}

We are grateful to S.R. Wallis, A. Ishiwatari and an anonymous reviewer for their valuable suggestions and critical comments on the manuscript.

\section{References}

Arakawa, Y., Saito, Y. and Amakawa, H. (2000) Crustal development of the Hida belt, Japan: Evidence from $\mathrm{Nd}^{-}$ $\mathrm{Sr}$ isotopic and chemical characteristics of igneous and metamorphic rocks. Tectonophysics, 328, 183-204.

Arakawa, Y., Kouta, T. and Kanda, Y. (2001) Geochemical characteristics of amphibolites in the Oki metamorphic rocks, Oki-Dogo Island, southwestern Japan: mixed occurrence of amphibolites with different geochemical affinity. Journal of Mineralogical and Petrological Sciences, 96, 175-187.

Bence, A.E. and Albee, A.L. (1968) Empirical correction factors for the electron microanalysis of silicates and oxides. Journal of Geology, 76, 382-403. 
Dallmeyer, R.D. and Takasu, A. (1998) ${ }^{40} \mathrm{Ar} /{ }^{39} \mathrm{Ar}$ mineral ages from the Oki metamorphic complex, Oki-Dogo, southwest Japan: implications for regional correlations. Journal of Asian Earth Sciences, 16, 437-448.

Dasgupta, S., Sengupta, P., Guha, D. and Fukuoka, M. (1991) A refined garnet-biotite $\mathrm{Fe}-\mathrm{Mg}$ exchange geothermometer and its application in amphibolites and granulites. Contributions to Mineralogy and Petrology, 109, 130-137.

Hayase, I. and Ishizaka, K. (1967) Rb-Sr dating on the rocks in Japan (I)-southwestern Japan. Journal of the Japanese Association of Mineralogists, Petrologists and Economic Geologists, 58, 201-212 (in Japanese with English abstract).

Hickey, R.L. and Frey, F.A. (1982) Geochemical characteristics of boninite series volcanics: implications for their source. Geochimica et Cosmochimica Acta, 46, 2099 $-2115$.

Hiroi, Y. (1978) Geology of the Unazuki District in the Hida Metamorphic Terrain, central Japan. Journal of the Geological Society of Japan, 84, 521-530 (in Japanese with English abstract).

Hiroi, Y. (1981) Subdivision of the Hida metamorphic complex, central Japan, and its bearing on the geology of the Far East in pre-Sea of Japan time. Tectonophysics, 76, 317-333.

Hiroi, Y. (1983) Progressive metamorphism of the Unazuki pelitic schists in the Hida terrane, central Japan. Contributions to Mineralogy and Petrology, 82, 334-350.

Hiroi, Y. (1984) Petrography of Unazuki pelitic schists, Hida terrane, central Japan (part 2)-bulk rock compositions. Bulletin of Faculty of Education, Kanazawa University, Natural Sciences, 33, 69-78 (in Japanese with English abstract).

Holland, T. and Blundy, J. (1994) Non-ideal interactions in calcic amphiboles and their bearing on amphibole-plagioclase thermometry. Contributions to Mineralogy and Petrology, 116, 433-447.

Hoshino, M. (1979) Two-pyroxene amphibolites in Dogo, Oki islands, Shimane-ken, Japan. Journal of the Japanese Association of Mineralogists, Petrologists and Economic Geologists, 74, 87-99.

Ishiga, H., Suzuki, M., Iizumi, S., Nishimura, K., Kagami, H. and Tanaka, S. (1989) Western extension of Hida terrane: with special reference to gneisses and mylonites discovered in Mizoguchi-cho, western part of Daisen, Tottori Prefecture, Southwest Japan. Journal of the Geological Society of Japan, 95, 129-132 (in Japanese).

Isozaki, Y. and Maruyama, S. (1991) Studies on orogeny based on plate tectonics in Japan and new geotectonic subdivision of the Japanese Islands. Journal of Geography, 100, 697-761 (in Japanese with English abstract).

Jin, F. and Ishiwatari, A. (1997) Petrological and geochemical study on Hida gneisses in the upper reach area of Tetori river: Comparative study on the pelitic metamorphic rocks with the other areas of Hida belt, Sino-Korean block and Yangtze block. Journal of Mineralogy, Petrology and Economic Geology, 92, 213-230 (in Japanese with English abstract).

Kobayashi, H., Matsumoto, Y. and Hoshino, M. (1980) OkiDogo. Excursion guidebook of the $87^{\text {th }}$ annual meeting of the Geological Society of Japan, 1-39 (in Japanese).

Komatsu, M., Ujihara, M. and Chihara, K. (1985) Pre-Terti- ary basement structure in the Inner zone of Honshu and the North Fossa Magna region. Contributions from the Department of Geology and Mineralogy, Niigata University, 5, 133-148 (in Japanese with English abstract).

Komatsu, M., Nagase, M., Naito, K., Kanno, T., Ujihara, M. and Toyoshima, T. (1993) Structure and tectonics of the Hida massif, central Japan. Memoirs of the Geological Society of Japan, 42, 39-62 (in Japanese with English abstract).

Leake, B.E. (1978) Nomenclature of amphiboles. Mineralogical Magazine, 42, 533-563.

McLennan, S.M. (1989) Rare earth elements in sedimentary rocks: Influence of provenance and sedimentary processes. In Geochemistry and mineralogy of rare earth elements (Lipin, B.R. and McKay, G.A. Eds.). Mineralogical Society of America Reviews in Mineralogy Vol. 21, 169 -200 .

Meschede, M. (1986) A method of discriminating between different types of mid-ocean ridge basalts and continental tholeiites with the $\mathrm{Nb}-\mathrm{Zr}-\mathrm{Y}$ diagram. Chemical Geology, 56, 207-218.

Miyamoto, T., Hayasaka, Y., Kano, A., Naka, T. and Sugata, Y. (2000) Geotraverse of the Chugoku Mountains (2): Hida belt-Hida marginal belt-Oeyama ophiolite-Akiyoshi belt-Maizuru belt. Excursion guidebook of the $107^{\text {th }}$ annual meeting of the Geological Society of Japan, 135146 (in Japanese).

Naito, K. (1993) Geochemical investigation of the Hida metamorphic rocks. Memoirs of the Geological Society of Japan, 42, 21-37 (in Japanese with English abstract).

Nakamura, Y. and Kushiro, I. (1970) Compositional relations of coexisting orthopyroxene, pigeonite and augite in a tholeiitic andesite from Hakone volcano. Contributions to Mineralogy and Petrology, 26, 265-275.

Ohta, M. (1963) Oki metamorphics. Journal of the Japanese Association of Mineralogists, Petrologists and Economic Geologists, 49, 189-205 (in Japanese with English abstract).

Ohta, R. (1962) Geological map of Japan, 1:50,000; Yonago. Geological Survey of Japan, Tsukuba.

Ota, K. and Itaya, T. (1989) Radiometric ages of granitic and metamorphic rocks in the Hida metamorphic belt, central Japan. Bulletin of the Hiruzen Research Institute, Okayama University of Science, no. 15, 1-25 (in Japanese with English abstract).

Pearce, J.A. (1983) Role of the sub-continental lithosphere in magma genesis at active continental margins. In Continental basalts and mantle xenoliths (Hawkesworth, C.J. and Norry, M.J. Eds.), 230-249.

Pearce, J.A. and Cann, J.R. (1973) Tectonic setting of basic volcanic rocks determined using trace element analyses. Earth and Planetary Science Letters, 19, 290-300.

Sawada, Y., Tsunogai, T., Yamasaki, H., Kobayashi, S. and Murakami, H. (2000) Oki-Dogo, SW Japan. Excursion guidebook of the $107^{\text {th }}$ annual meeting of the Geological Society of Japan, 115-134 (in Japanese).

Shibata, K. and Nozawa, T. (1966) K-Ar ages of Hida metamorphic rocks, Amo-Tsunokawa area and Oki area, Japan. Bulletin of the Geological Survey of Japan. 17, 410-416.

Shibata, K., Nozawa, T. and Wanless, R.K. (1970) Rb-Sr geochronology of the Hida metamorphic belt, Japan. 
Canadian Journal of Earth Sciences, 7, 1383-1401.

Sohma, T. and Kunugiza, K. (1993) The formation of the Hida nappe and tectonics of Mesozoic sediments: The tectonic evolution of the Hida region, Central Japan. Memoirs of the Geological Society of Japan, 42, 1-20 (in Japanese with English abstract).

Sohma, T., Kunugiza, K. and Terabayashi, M. (1990) Hida metamorphic belt. Excursion guidebook of the $97^{\text {th }}$ annual meeting of the Geological Society of Japan, 27-58 (in Japanese).

Sun, S.-s. and McDonough, W.F. (1989) Chemical and isotopic systematics of oceanic basalts: implications for mantle composition and processes. In Magmatism in the ocean basins (Saunders, A.D. and Norry, M.J. Eds.). Geological Society Special Publication No. 42, 313-345.

Suwa, K. (1979) Biotite schist and leptite from the Kitamatadani and Kasa-dani of the upper Katakai-gawa area, Toyama Prefecture. In The basement of the Japanese Islands-Professor Hiroshi Kano memorial volume (The committee of the "Professor Hiroshi Kano memorial volume" at Akita University Ed.). 15-27 (in Japanese).

Suzuki, K. and Adachi, M. (1991) The chemical Th-U-total $\mathrm{Pb}$ isochron ages of zircon and monazite from the Gray granite of the Hida terrane, Japan. Journal of Earth
Sciences, Nagoya University, 38, 11-38.

Suzuki, K. and Adachi, M. (1994) Middle Precambrian detrital monazite and zircon from the Hida gneiss on OkiDogo Island, Japan: their origin and implications for the correlation of basement gneiss of Southwest Japan and Korea. Tectonophysics, 235, 277-292.

Suzuki, M., Nakazawa, S. and Osakabe, T. (1989) Tectonic development of the Hida Belt-with special reference to its metamorphic history and late Carboniferous to Triassic ogogenies. Memoirs of the Geological Society of Japan, 33, 1-10 (in Japanese with English abstract).

Taylor, S.R. and McLennan, S.M. (1985) The continental crust: its composition and evolution. pp. 312, Blackwell Scientific Publications, Oxford.

Tatsumi, Y. (1995) Subduction zone magmatism-A contribution to whole mantle dynamics. pp. 186, University of Tokyo Press, Tokyo (in Japanese).

Yamashita, K. and Yanagi, T. (1994) $\mathrm{U}-\mathrm{Pb}$ and $\mathrm{Rb}-\mathrm{Sr}$ dating of the Oki metamorphic rocks, the Oki Island, Southwest Japan. Geochemical Journal, 28, 333-339.

Manuscript received; 18 February, 2002

Manuscript accepted; 19 June, 2002 